\title{
Pearl Trade in the Persian Gulf during the 19th Century
}

\author{
Abed Al-Razzak Al-Maani ${ }^{1} \&$ Saleh Alsharari ${ }^{2}$ \\ ${ }^{1}$ Centre of studies, Consultation and Community Development, Al-Hussein Bin Talal University, Ma'an, Jordan \\ ${ }^{2}$ Department of Media and Strategic studies, College of Art, Al-Hussein Bin Talal University, Ma'an, Jordan \\ Corresponding: Abed Al-Razzak Al-Maani, Centre of studies, Consultation and Community Development, \\ Al-Hussein Bin Talal University, P.O. Box 20, Ma'an, Jordan. Tel: 962-775-639-020. E-mail: \\ almaani_1@yahoo.com
}

Received: October 14, 2013 Accepted: November 8, 2013 Online Published: December 10, 2013

doi:10.5539/ach.v6n1p43 URL: http://dx.doi.org/10.5539/ach.v6n1p43

\begin{abstract}
This research provides an overview of pearl trade in the Persian Gulf during the $19^{\text {th }}$ Century, depending on the historical sequence methodology at the region of collapse of Arabian traditional maritime trade systems, in light of capitalist economic transformations and their international variables. Here we address the unique nature of pearl hunting, until it had become a profession available to all people of the Persian Gulf in particular, thereby showing their skills in this profession and developing it as a substitute for their maritime trade, which sustained substantial losses due to dominance of the European trade fleets. Further, we review the pearl trade centers and their famous markets; e.g. Bahrain, Qatar, Dalma Island, and Lengeh, due to their strategic locations as fisheries abounding with precious pearls.
\end{abstract}

Keywords: pearl trade, Persian Gulf, ports, commercial centers and their markets

\section{Introduction}

Trade relationships between Asia and Europe have never been interrupted since the ancient times; as the Europeans were in continuous need for many commodities from the East; foremost of which were spices, silk, and pearls. In addition, some of them were in dire need for markets to offer their products for sale; e.g., wool, of which the English produced large quantities in excess of their actual need.

Trade between Asia and Europe proceeded through several channels, passing by centers, which witnessed remarkable commercial boom, particularly during the $17^{\text {th }}$ Century, when competition became fiercer between the Portuguese, Dutch, English people, and others. Given its central location between the East and West, the Persian Gulf formed what we can call a hub or a pivot point for that trade. The majority of trade passed through the Persian Gulf, whether those reaching its northern parts to transport the goods by land from thence to the Mediterranean ports, and from thence to Europe, or other goods, which reached its southern parts to continue its journey by sea, to go through the Red Sea or the Cape of Good Hope route, and from thence to Europe as well. This situation brought about boom to many Gulf ports, until they became highly important stations as centers for commercial activity.

Ports of the Persian Gulf, like other ports, are considered the pivotal mainstay of commercial communication and a dimension of the commercial activity square without which this activity would collapse. The other three dimensions are means of transport and their suitableness, commodities and their merchantability, and the way of dealing with traders (Othman, 1991). In fact, the Persian Gulf the most outstanding points of that communication, which remained uninterrupted during any period of history, especially between Europe and Asia; rather, it flourished heavily since the late 16th Century (Ameen, 1987).

The flourishing of ports located along the Persian Gulf's sides is clear evidence for the importance of its location, and the importance of these ports in the commercial relations between the East and Mediterranean Region. A researcher expressed this fact saying, "Without the Persian Gulf, there would be no commercial importance at all for the Eastern part of the Mediterranean sea region in the international trade" (Al-Shami, 1980).

The Persian Gulf route, or rather, the middle route, is regarded as the most important and oldest of all roads; the trade commodities had reached the top of the Gulf, where some part of them moved directly from thence to the Levant through the dessert, while the largest part of these commodities was transported to Baghdad. From 
Baghdad, a network of caravan routes branched out from thence in different directions, especially towards the Mediterranean seaports where large quantities of commodities were arrived and transported to Europe (Ameen)

Thanks to its location in the heart of the ancient world, the Persian Gulf brings the land crossing, which extends through Iraq and Syria, near to the Far East Countries, thus conferring upon this maritime arm commercial importance better than the Red Sea Route. As a result, the India-Europe trade always went through this route (Persian Gulf route), until the Indian route was discovered through Cape of Good Hope route (Olivier, 1965).

There is no doubt that the Gulf's Arabs were familiarized with the sea since a long time ago, they played an influential role in both trade and navigation, and effectively contributed to prosperity of trade in particular. The land caravans and ships had come loaded with variety of goods, unloaded them in the Gulf markets to be re-exported again to different destinations, and from thence to Europe. Furthermore, the land caravans had come from Iraq, Levant, Egypt, and the Arabian Peninsula, unloaded their cargo in the Gulf markets, and then returned to their homeland loaded with the goods from China, India, and Eastern Africa.

On the hand, ships coming from India and South Eastern Asia had unloaded their cargo in the Gulf markets as well, and returned to their homeland loaded with goods from the Mediterranean Sea countries. Over the time, this commercial interaction evolved, and the Persian Gulf not only became a point of contact between two nearby places; but also it became a point of contact between the farthest East and West known at that time (Al-Askari, 1998). However, this contact was not direct, as the goods, in order to reach Europe for example, had to pass through several routes and markets, serving as on-the-route commercial stations.

Goods coming from the East were transported from Malabar port and other East ports to the Persian Gulf's ports such as Hormuz and Basra, and moved from thence to Baghdad through Tigris and Euphrates Rivers. From Baghdad, the goods moved by land in parallel with the west bank of the latter river, where the caravans headed towards the coastal cities of Levant, particularly Damascus and Beirut.

\section{Collapse of Traditional Trade Systems}

The economic transformations, taking place during the second half of the $19^{\text {th }}$ century due to introducing modern means of transport to the Persian Gulf, caused a hard blow to the Arab traditional shipping vessels, which became unable to compete against steam ships in the area of commercial transport along India-Persian Gulf line. As such, they performed a secondary role through distributing the goods loaded on the European ships for all regions of the Persian Gulf after they were the main carrier of these goods (Al-Fares, 2000). In addition, the collapse of traditional ships-based transport brought about decline to manufacturing industry, due to stopping the building of large vessels, which were used to transport to the goods, and which were one of the most important professions in the region. This caused the people of that region to resort to working in the only remaining profession; e.g. pearl hunting (Ibid). Lorimer said that the Persian Gulf's ships hardly sailed to Zanzibar or the Red Sea; rather, their voyages were limited to Karachi, and sometimes Bombay and Jeddah (Al-Fares, 2000)

Belli estimated the number of ships operating in trade in the coast of emirates from Ras Al Khaimah to Sharjah in 1826 at 122 ships, which increased up to 172 ships in 1831; i.e. 50 ships were added in a five-year period to work in foreign trade (Lorimer). In 1863, the number of ships engaged in foreign trade at the same ports went down up to 102 ships of which 26 large ships were operating at India-Africa lines, while the small ships of lesser loads were operating at the nearby lines. In 1881, the number of ships operating at the same lines remained 26 ships (Al-Fares); a fact which bears witness to the decline in foreign trade in 17 years.

Following the English occupation of Oman Coast in 1820, the contribution of Arab traders to international trade was limited to being agents or distributors of the European manufactured and semi-manufactured commodities as well as strategic commodities, which were monopolized by the European capitalist companies for trading purposes, thus causing collapse of the whole handicraft production in that period. The commercial dealing was based on an order for goods submitted by the trader to the local agent of the European company within a particular period, in consideration of the payment of one tenth or more of their price. When the goods arrived, the agent collected the remaining price from the trader in consideration of a letter to deliver the goods at the port. In turn, the trader had to take all customs procedures and pay taxes and customs duties the majority of which were paid to the Emirate's ruler to finance the municipal authority, which formed an important part of the national income (Ministry of Information, 1979).

Moreover, the collapse of traditional ships-based transport brought about decline to a corresponding industry; namely, the Arab shipbuilding industry (The Gulf's Arabs) which stopped building large ships that were used for transporting commercial commodities. Before 1862, Muscat Port, apart from its importance in international trade, served as a center for distributing the local goods to abroad, and the trade caravans came to it from the internal 
places loaded with locally produced commodities such as medical herbs, leather, honey, and raisins, while they came back loaded with the commodities coming to the port from India and Europe; e.g. rice, spices, sugar, and cloth (Great Britain, India Office, Marine Records, 1792).

The period between 1862 and 1872 witnessed a decline in the important commercial centers in the Gulf, such as Muscat Port, which experienced rapid decline as a commercial center. Similarly, the other ports were affected by the new situations and their importance receded, although they had been major points for the international trade movement at that time; e.g. Juwa, Calicot, Surat, and Dibol in the Western India, and they were replaced by Bombay, Madras, and Kolkata. For the Arab Gulf, apart from the recession of Muscat Port, ports of Oman Coast were also affected and the ports of Bahrain and Bushehr had emerged. Further, the ports of Jeddah, Jizan, Massawa, and Aydhab in the Red Sea receded, while Suez and Aden acquired additional importance (Al-Fares \& Al-Naquib).

Furthermore, Basra Port (West Persia and Levant. Marine Records, 1970), flourished again after a period of recession in the middle of the $19^{\text {th }}$ century, due to the opening of ferryboats sea line in 1861 where East India Company began dispatching its voyages in 1862 .

Bandar Abbas Port (Al-Arab Press, 1982) flourished again as a center for trade exchange, and its activity covered a large area of south central Asia, yet it lost its importance in the late $19^{\text {th }}$ century. The same is true for Lengeh Port, which remained a center for assembly and distribution of commodities for a long period, yet following 1902, it receded to be replaced by Dubai Port. Also, there was Khorramshahr Port located at the assembly point between Shatt al-Arab and Karun River. This port took place in the late $19^{\text {th }}$ century of the inauguration of river navigation line over Karun River (Al-Fares).

Kuwait is one of the most important ports in the Persian Gulf in the $19^{\text {th }}$ century. In 1845, an English report pointed out that Kuwait Port accommodates all ships of the British fleet, without feeling any narrowness due to the anchoring of all these ships at the same time (Abu Hakimah, 1970). In 1866, ships of East India Company began to sail to Kuwait. In this regard, Lorimer stated that transportation trade of goods in Kuwait was primarily limited to the upper and western part of the Gulf and Shatt al-Arab, the usual boundaries of this trade were Al Qutaif in the south and Basra in the north, while ships used in this trade were often away from Kuwait for over a couple of months and were estimated at around 36 ships.

Among the other important results, the Indian traders took control over the largest part of commercial activity of Persian Gulf's cities, as the Indians played a primary role for hundreds of years in the region's trade; even they monopolized the trade following the middle 19th century due to their strong association with the Indian Sub-continent as well as the credit facilities they obtained and benefits they gained from the opportunities provided by modern commercial techniques and transport.

On the other hand, the Arab traders engaged in the distribution trade which was active before 1862, due entirely to lack of commercial expertise, capabilities, as well as flexibility to adapt with the new situations. Due to transformations that overwhelmed the Gulf region after the introduction of modern means of transportation which had negative impact on ship-building industry, the population of that region had no other choice but to adjust themselves to the new situations and engage in the remaining profession; i.e. pearl hunting (Abu Hakimah).

\subsection{Pearl Diving}

Economy of the Persian Gulf depended mainly on the sea for pearl hunting, fishing, and trade, in addition to other economic activities; e.g. pasturage and limited agriculture in the oasis, land trade, and traditional handicraft industries such as shipbuilding, leather industry, and tents industry. Indeed, the land trade occupied a prominent standing in the region's economies, with the exploration of trade in pearls.

In fact, pearls are rated among the most important commercial commodities in the Persian Gulf region during the $19^{\text {th }}$ century in Bahrain, Qatar, Kuwait, Oman Coast, and coast emirates (Olivier's). This region was known for pearl trading until they had become mutually associated, so that no sooner had the name of Persian Gulf been uttered than the pearl came to the mind, although there were other regions producing large quantities of pearls, yet in lower quality, extending along the shores of Pacific Ocean and China coasts (Othman). Further, the pearl oysters are spread out in the warm regions of the Pacific Ocean, and in the different regions of relatively quiet and shallow water (Al-Fil, 1985), yet the geological formation of the seabed, heat, and shallowness of the Persian Gulf makes it one of the best places for existence of pearl oysters (Ibid).

Pearls, as an important commodity in the Persian Gulf region, had provided work opportunities for a large number of low-class workforces, in addition to their masters with their large and small-size ships. As is well 
known, this trade is typically preceded by fishing process having its particular ceremonies, arrangements, and seasons.

Fishing boats had been assembling in May month, when the fishing season begins and lasts throughout the months of summer (Othman \& Saldanha, 1986). This period was suitable for diving, upon the blow of winds and rainfall (Al-Qattami, 1976). However, diving was completely held on some religious occasions; e.g. during the month of Ramadan (Al-Naser). Each boat had been carrying tens of highly-efficient divers, equipped with many heavy stones and ropes. Ropes were tied up around the bodies of divers, and their noses were filled with yellow wax or some other suitable substance, and each diver had a net or feedbag, while there was another rope tied up with a rope of about $30 \mathrm{~kg}$ which the diver held by hand to attract him to the seabed.

When the pearl diver had reached the seabed, he collected the pearls using a sharp knife, yet when he had some breathing trouble, he attracted the rope through a particular sign to be pulled to the boat deck to take some rest for a while before repeating the same process (Othman). Meanwhile, other divers descended to the water in groups, while a group of the same divers' number was always preset on boat deck, to push them into, attract them from the water, and pick up the oysters from them (Ibid).

There were seasons for pearl hunting other than the summer months, yet they were less important and less productive. The first of these seasons was "Al-Khanjiya" which began in April, during which small ships were used at the nearby shallow pearl fisheries. The second season was known as Al-Rada "Apostasy"; i.e. getting back to the sea for pearl hunting in October, while small-size ships were used as well. The period of that season ranged between ten to forty days. The third season was known as "Radida", following the end of "Al-Rada" Apostasy season in November, and lasted a few weeks only (Al-Shamlan, 1993; Al-Qattami). In the majority of diving seasons, some diving ships move to the nearby ports to be equipped with water and food and to repair the ships and then return to continue their activity (Al-Rasheed, 1978).

In this context, it is worth mentioning that pearl hunting ships went in most cases to the pearl-rich ports and shores regardless of their ownership, as diving for pearl oysters was available to all without conditions other than the payment of specified amounts to the ruler of province in which pearls were collected (Abu Hakimah, p. 129). Following the hunting of pearl from deep water, there comes the phase of selling pearls, which was typically made in the sea, as Al-Tawash (Al-Tawash) had bought the pearls from the Nukhza (See Eddi Share, Arabicized Persian words) in consideration of cash price.

The pearl trader had been moving among the diving ships over a small boat carrying his money, and then takes the pearls to sell in the Gulf markets (Nukhza, 1976). Following the sale of pearls, the ship owner had been distributing the shares to the diving participants; i.e. owners of boats and divers according to a pre-defined agreement (Arab Book House, 1908As for traders, following the collection of pearls, they exported same to Iraq where the brisk markets took place in Basra and Baghdad. Basra exported the pearls to neighboring countries such as Turkey and Levant, and from thence they were exported to Europe (Saldanha). It was also exported to Macha through Muscat, and to Bushehr, Suart, and Kalkata, while traders transported them from thence to other places of India and to China and Tatars areas (Ibid).

The sale of Pearls was sometimes made according to a pre-defined arrangement, where the traders came together on a specified date at a specified place to meet the pearl hunters who brought what they hunt, each of them put his quantity in a bag carrying his name. Next, they had been opening the bag one by one, and placing their pearls in sieves of different holes over each other, and then sorted pearls by size: large pearls, followed by medium pearls, and small pearls, and then they offered them for sale in the market where each trader bought the required quantity (Al-Nasir) .

\subsection{Diving Available to All}

Since ancient ages, pearl fisheries were available to all Arabs residing in the Arabian coast, and although there were no boundaries for the tribes, the external boundaries of these fisheries were known to all, and intervention was impermissible. Further, the rulers were convinced that pearl diving was available to all unconditionally, other than the payment of specified amounts to the ruler of province in which pearls were collected (Abu Hakimah). Hence, pearl fisheries were regarded as public property, and nobody had a right to give privilege to third parties. Because the shallow water depends mainly in its economic feasibility upon the deep water, which provides it with oysters, the rulers' objections were not related only to non-intervention in the shallow water where their subjects had been hunting for pearls, but also involved abstention from using the fisheries located in the deep Persian Gulf as well (Al-Fares).

The first foreign attempts to exploit pearl fisheries took place in 1857, when Watson; a Bombay company, 
expressed a desire to carry out pearl hunting activities. When the matter was referred to Captain Felix Jones, he issued a report pointing out that this matter would inevitably lead to conflict and bloodshed; as a result, the English government rejected the request (History of the U A E, 1996).

Next, foreign attempts continued. In 1863, an English ship appeared in the Persian Gulf carrying trained divers and advanced equipment, yet the steps taken by the Political Resident with the consent of the Government of Bombay were sufficient to stop these attempt. In 1874 and 1890, upon a recommendation from the government of India, the English government rejected many proposals submitted by English companies to exploit pearl fisheries, and during the period between 1894 and 1903, it rejected all requests submitted by persons and companies of different nationalities to exploit these fisheries (Ibid).

Further, foreign attempts for pearl hunting in the Persian Gulf's fisheries continued, due entirely to wrong understanding of the principle of pearl hunting profession; being a right available to all, yet all meant the region's population only.

As for internal threats, they were acts of piracy against the diving ships and disputes that had arisen between the emirates along the coast due to pearl hunting. The English had signed an agreement with the ruler of coast Emirates during the big diving season (21May-21 November) 1835 (Saldanha), which was renewed annually. This agreement provided a stopping for all aggressive acts against pearl hunting ships, and then turned into a permanent peace treaty in 1853, under which the British Political Resident in the Persian Gulf became the last resort for dispute settlement; inter alia pearl-related disputes. The conflicts arose with no specified place or time, pearl fisheries were a battlefield, so the weak ships the owner of which failed to settle their disputes with their opponents were not able to take part in pearl diving for a season or more, yet the English were able to enforce security upon all (For further details on 1853).

In 1892, the British Government entered into a new agreement with the ruler of coast of emirates, obligating them not to enter into any undertakings or make any communications with third parties, and not to accept the presence of an agent representing any foreign state on their lands, unless the British government permitted, and not to pledge, sell, assign, or dispose of anything that might entitle foreigners to occupy a part of their lands, except for Britain (Ibid).

Thus, we find out that the English were able to abort all foreign attempts aiming to exploit pearl fisheries through imposing further restrictions to consolidate their authority, and to protect the region's interests against foreign threats as well, so they addressed circulars to all rulers of coast emirates, warning them from the grant of privileges to foreigners to hunt pearls and sponge in their areas (Ibid).

\subsection{Pearl Trading Centers and Markets in the Gulf}

\subsubsection{Bahrain}

Bahrain is considered as one of the most important and largest pearl trading centers in the Persian Gulf region, due to its abundant production on the one hand, and holding the "No.1" rank in export on the other hand. It consists of a number of Islands, the largest of which is Bahrain located in a region falling in the middle between Hormuz Strait and Shatt al-Arab, with 30 miles long and 9 miles width. This Island is characterized by a port with natural protection (Wilson), as well as many fresh-water sources and trees, particularly palm tree. Abundance of fresh-water sources was an attracting factor for trade ships (Al-Nabhani, 1942).

In fact, Bahrain is considered the major pearls market in the Gulf, in which pearls were pierced and then exported to abroad (Al-Qattami). It was also famous for shipbuilding industry, which had required recruiting hundreds of carpenters, and used large quantities of wood imported from India (Lorimer). David Wilson, who wrote a memorandum entitled "memorandum on pearl hunting in the Gulf" in the Royal Geographic Society Journal in 1833 reported that that the annual vale of pearls proceeds in Bahrain alone was estimated at two million and two hundred thousand German Krone, and it was believed that senior traders of India, Arab Peninsula, and Persia, who were dealing in pearls, had made their purchases through agents in Bahrain".

Lewis Belli, the British Political Resident at the Persian Gulf region during the period between 1862 and 1871, wrote several reports on the Gulf; one of which was entitled "Remarks on pearl oyster hunting places in the Gulf", to Bombay Geographical Society. This report pointed out, as mentioned by Belli, that "The majority of good pearls were sent to Bombay during the share skyrocketing, extraordinary prices were set for the good pearls, while large quantities of the pearls were sent to Baghdad. As a rule, Bombay market prefers the yellow-colored, round pearls, while Baghdad market prefers the white pearls and pearl grains, while the small pearls were mainly sent to Baghdad". Further, non-classified, bad-type pearls were sold in Iran, as they were used as ornamental tools (Lorimar). 
In 1902, Manama and Lengeh were the most important pearl markets in the Gulf region, as Manama took control over the middle region's trade, while Lengeh took control over the southern part of the Gulf. Due to strict rules imposed by the Iranian authorities, Lengeh trade began to turn in a considerable and large extent to Dubai, while the largest part of the pearls of Bahrain, Lengeh, and Dubai was exported to Bombay, from where they were classified and sent to the European and other markets, yet some of them were sent to Baghdad (Al-Fares).

James Moorerr, the British diplomatist and writer, compiled a book entitled "Journey across Persia, Armenia, and Anatolia Eyalet during 1808/1809" and another book entitled "Journey to Persia" in 1818. He had special interest in pearl trading in the Gulf. He wrote about the early $19^{\text {th }}$ century saying "The majority of pearl trading is now available in Muscat, and from thence the largest part is exported to Surat, while the clients of Indian traders are always present on site, while pearl hunters prefer to sell their product at a higher price, through less regular, in India instead of selling them to a single person in the Arabian Peninsula (Al-Fares).

\subsubsection{Dalma}

Dalma Island occupies the second rank following Bahrain. It acquired its importance as a commercial port for pearl trading due to its central location among the pearl fisheries. This unique standing was consolidated when the Iranian customs imposed strict rules on pearl trading, after it had seized Lengeh Emirate at the eastern coast of the Persian Gulf. The majority of population at the eastern coast of the Persian Gulf had come to dive in the surrounding heart Hiras (Al-Shamlan) "pearl fisheries" in Dalma Island affiliated to the Emirate of Abu Dhabi at present (coast emirates).

Further, the ships heading for it were safe from winds and tempests. Dalma Island was populated throughout the year, and its population had increased in the diving season to reach up to ten times their original number (Al-Otaiba, 1971). The island had a small market for selling supplies, while the pearl traders and financiers came to it to buy pearls and redeem their debts (Lorimer). May traders come to Dalmah Island including traders of Lengeh, Persian Coast, as well as large numbers of Indian traders known in the international pearls market of Bombay as (Muse Bazaar), in addition to the auctioneers, where supply and demand deals took place for divers and mariners (Rahma, 1990).

\subsubsection{Lengeh}

Lengeh, Bushehr, Bandar Abbas, and Bahrain were the main ports in the Persian Gulf during the last quarter of the $19^{\text {th }}$ century. Given their strategic location near Hormuz Strait, they became a point of contact for trade among the Persian Gulf's ports. It was also an important pearl export port, depending mainly on the production of pearl fisheries in the Arabian coast (Al-Fares). Further, Lengeh acquired special importance due to being a center for collecting and selling the commodities for a long period, yet this importance receded following 1902 to be replaced by Dubai (Ibid).

\subsubsection{Kuwait}

Kuwait occupied an outstanding position in pearl trade, in spite of its limited contribution to export. In 1862, Palgrave came to Kuwait and said it was the most active and dynamic Gulf port. Falias said "Kuwait had one of the best ports in the world, extending for over two miles, and sail boats overcrowd at that port in paralleled lines" (Arab Book). In fact, this profession witnessed boom during the reign of Sheikh Mubarak Al-Sabah, especially in 1912. In that year, the number of diving ships reached up to 812 ships, with income amounting to Indian Rupee six million, so that year was named "The Year of Heyday".

\subsection{Pearls in the Gulf Exports Trade}

Lorimer didn't exaggerate when he said In his book " Gazetteer of the Persian Gulf, Oman and Central Arabia" that "Pearl hunting is the premier industry of the Persian Gulf; it is, besides being the occupation most peculiar to that region, the principal or only source of wealth among the residents of the Arabian side. Were the supply of pearls to fail, the trade of Kuwait would be severely crippled, while that of Bahrain might - it is estimated - be reduced to about one-fifth of its present dimensions and the ports of Trucial Oman, which have no other resources, would practically cease to exist".

Pearls trade constituted the main economic base for the Arabian Gulf states including the coast emirates. The governor's income came mainly from taxation; the income of each Sheikhdom varied according to the Sheikhdom size and fortune. In addition, the amount of the governor's income differed according to his power and his influence on the economic activities (Al-Fares).

Many taxes were imposed on diving ships by the governors. Most prominent of which was the naub or tax on boats which was originally imposed by Sheikh Al Bahrain to enable him to manufacture armed ships in order to 
protect his pearl fisheries in general. The tax was one share of the total cargo of any ship anchored to his coasts. This tax became a source of income for governors, then it was imposed on the ships heading to the pearl fisheries and after that it was extended to be imposed all over the region from Kuwait to Ras Musandam. The total amount of this tax in 1872 In Bahrain and Qatar reached about 10 thousand Rupees and 20 thousand Rupees in the coast extending from Abu Dhabi to Al Hasa.

The Taraz or poll tax is a tax collected from the pearls brought by ships. It equaled one share and its amount depended on the amount of the pearls, it didn't usually exceed 4-100 Rupees, which was considered a heavy tax (Al-Fares). There were other kinds of taxes such as Alshwfa tax that was collected in urgent situations only, the Selling tax imposed on sold pearls; Alradf tax collected when war was expected to outbreak; Alkhenshia tax was imposed on houses; and the sour riyal tax which was collected to cover the expenses of reconstructing fortification and defense means (Lorimer). There were also taxes imposed on some of agricultural products. The governor himself might have been pearl merchant or a trader of other commodities. On the other hand, customs constituted a large and main part of not only the budget of the state but also the governors' income.

One of the traders estimated the total income of a sheikh in Kuwait at about four million dollars annually. A big part of this amount was from customs as shown in the following table:

Table 1. Government income (tax) by activity

\begin{tabular}{lc}
\hline Tax type & Amount/ dollar \\
\hline Tax on sheep brought to the city & 2000 \\
Tax on pearl divers & 60000 \\
Marine tax & 150000 \\
Tax on camels brought to the city to be sold & 1500 \\
Tax on imports & 20000 \\
Tax on bringing fish to Kuwait & 7000 \\
Interest on money gained by traders & 8000 \\
Total & $* 2485008$ \\
\hline
\end{tabular}

Source: Lorimer, Part 4, page 1768

Table 1 shows that about $63 \%$ of the governor's income came from trade and activities related to it. Lorimer estimated the annual income of the governor of Abu Dhabi at 6711 sterling pound from different sources of which pearl trade constituted 82\%. Dubai governor's income was about 4569 sterling pound. Al Sharjah governor's income was much lower, 2227 sterling pound, because many of the rulers of the affiliated areas used to keep the money of the customs for themselves, and not every person in the Sheikhdom paid taxes. There were tax exemptions that included members of the ruling family, friends of the governor and his servants. The governor paid little amount of expenses such as salaries of his guards who were in the main villages of the Sheikhdom (Zahlan, 1978).

The pearl was special component of the Arabian Gulf exports and was of great importance among other exports. Pearls exports amounted to $75 \%$ of the total exports of the Arabian Gulf at the end of the nineteenth century to reach over than 28 million Rupees (AlFares). In 1865 Colonial Belli estimated the pearl total revenues in the Arabian Gulf at 400 thousand sterling pounds. The exports increased in 1873-1874 to 7900000 Rupees. During the period 1875-1877 the total pearl exports of Kolkata, Bombay and Karachi equaled 2,982,050 Rupees (Lorimer). In 1873-1874 the total pearl exports of exporting harbors in the states' coasts of Oman, Bahrain, Lengeh, Muscat, Bushehr, and Bandar Abbas equaled 625933 sterling pound. A little while after twenty-eight years i.e. in 1902-1903, the pearl exports amounted to 1307241 sterling pounds as the value of the exported sterling reached about 16 million sterling pounds. For example in 1873-1874 in Trucial states, the pearl exports reached 1180000 Rupees of total exports that equaled 1338695 Rupees. Thus, the pearl trade exceeded all other exports (Ibid).

To further clarify the actual local trade volume in the Arabian Gulf. The following Tables (2) and (3) include data that covers the period starting from the second half of the nineteenth century to 1904-1905. 
Table 2. Gulf Workforce and revenues in pearl hunting in 1906/1907

\begin{tabular}{lccccc}
\hline state & population & $\begin{array}{c}\text { Diving } \\
\text { ships }\end{array}$ & $\begin{array}{c}\text { Population working in } \\
\text { pearl hunting }\end{array}$ & $\begin{array}{c}\text { Percentage of Population } \\
\text { working in pearl hunting }\end{array}$ & $\begin{array}{c}\text { Pearl trade } \\
\text { revenues } \\
\text { (Rupees) }\end{array}$ \\
\hline Bahrain & 99,075 & 917 & $17, .633$ & $18 \%$ & $12,603,000$ \\
Oman & 72,000 & 1215 & 22,045 & $31 \%$ & $8,000,000$ \\
coast & & & 12,890 & $48 \%$ & - \\
Qatar & 27,000 & 817 & 6,200 & $20 \%$ & $1,347,000$ \\
Kuwait & 37,000 & 461 & & &
\end{tabular}

Source: Lorimer J.G., Gazetter of the Persian Gulf-Historical, Part 2,2252

Table 3. Total pearl trade revenues from 1893 to 1904

\begin{tabular}{lccccc}
\hline Year & $\begin{array}{c}\text { Muscat } \\
\text { (USD) }\end{array}$ & $\begin{array}{c}\text { Lengeh } \\
\text { (Rupee) }\end{array}$ & Bahrain (Rupee) & $\begin{array}{c}\text { Oman coast } \\
\text { (Rupee) }\end{array}$ & Annual total/ (Sterling pound) \\
\hline $1889-1900$ & 50000 & 3399900 & 6824430 & 7749990 & 689533 \\
$1893-1894$ & 50000 & 4205000 & 3693750 & 5000000 & 483767 \\
$1896-1897$ & 30000 & 3856000 & 5167000 & 70000000 & 545520 \\
$1903-1904$ & 22000 & 4905000 & 10275300 & 9000000 & 1439975 \\
\hline
\end{tabular}

Table 2 shows data about the workforce working in pearl trade while table 33 shows data about the monetary trade of this industry. Despite the fact that we do not have accurate data about the income level or the total income in these states during that period, the money amount stated in these tables represent high rate of income according to the scale of this period.

The reason behind measuring income by the Indian Rupee is that the pearl Arabian trade used to be directed towards India especially Bombay. We should take into consideration that the population working in pearl mentioned in Table 2 does not represent only the local workforce but also immigrants, especially Bedouin, took part in this seasonal activity. The population doesn't include other persons who benefited from this trade such as ship makers, freight work, trade, and cities markets (AlNaquib).

Table 3 shows that huge number of people and ships from Oman coast worked in this industry, but their income does not suit this number compared to Bahrain; because the income stated was recorded by traders and British agents in Dubai. However, most workers and ships were from Abu Dhabi. They worked around Dalma Island; accordingly it wasn't officially recorded in Dubai or Al Sharjah. Besides, most of selling bargains were conducted at sea or in Dalma Island directly.

Seemingly, revenues of pearl trade were considered a cornerstone in the overall trade activities of the Arabian Gulf Sheikhdoms during the 19th century; and exceeded other maritime activities.

\section{Conclusion}

This study came to the following findings:

1) "Pearl" was considered an important and brisk trade in the $19^{\text {th }}$ century, especially in the Persian Gulf region; e.g. Bahrain, Qatar, and Kuwait. It was the first profession that provided a large number of workers with work opportunities, in addition to their superiors and ships within particular seasons and different ceremonies.

2) The collapse of trade systems during the second half of the $19^{\text {th }}$ century brought about transformation into new maritime systems that superseded the Arab traditional shipping systems, as they were unable to keep abreast with the modern commercial ships.

3) The Persian Gulf's economy depended mainly on sea for pearl hunting and fishing, in addition to pasturage, limited agriculture, leather and tent industry. The maritime trade occupied an outstanding position in the region's economies, with the exploration and extraction of pearls.

4) There had been multiple pearl trade centers and markets in the Persian Gulf; e.g. Bahrain, Delma Island, Lengeh, and Kuwait in varying percentages. Pearls became the most important exports of these countries and their main source of income. As a result, various customs duties were imposed, which increased the revenues of rulers and governors of the region. 
5) Several currencies were used to calculate the funds of pearl trade exports; foremost of which were the Indian Rupee, due to frequent export to India and Bombay in particular. Thus, revenues from pearl trade formed the mainstay and cornerstone for Persian Gulf's trade in the $19^{\text {th }}$ century.

\section{References}

Abdullah, M. (1996). History of the United Arab Emirates 1797-1965 (Vol. 1). London: London Center for Arab Studies.

Abu Hakimah, M. (1970). History of Kuwait (S. 2). Kuwait: Kuwait History Committee.

Al-Askari, I. (1972). Trade and Navigation in the Persian Gulf during the Abbasi period.

Al-Fares, M. (2000). Economic Situations in the Cost Emirate 1862-1965 (1st ed.). Abu Dhabi: Emirates Center for Strategic Studies and Researches.

Al-Fil, M. R. (1985). Historical Geography of Kuwait (2nd ed.). Zat Al-Salasel, Kuwait.

Al-Nabhani, K. (1942). Al-Tuhfa Al-Nabhaniya in the History of Arabian Peninsula. Cairo.

Al-Nasser, H. (1998). Commercial Activity in the Arabian Peninsula in the late Middle Ages, 1250-1517. Egyptian Anglo Bookshop, Cairo.

Al-Otaiba, M. S. (1971). Economies of Abu Dhabi in the past and present. Beirut.

Al-Qattami, I. (1976). The confused person's guide in sea world (3rd ed.). Kuwait: Kuwait Government Press.

Al-Qina'y, Al-Khososi, A. N. A., \& Badr, E. (1982). History of shipbuilding industry in Kuwait and its different activities, Kuwait, Kuwait Foundation for the Advancement of Sciences (KFAS). Countries, Arabic Historian Journal, Baghdad.

Al-Rasheed, Y. A. (1978). History of Kuwait. Beirut: Life Bookshop publications.

Al-Rumaihi, G. (1976). Issues of political and social change in Bahrain and Kuwait. Kuwait: Al-Wihda Publishing and Distribution Establishment.

Al-Shami, A. (1980). Commercial Relations between the Gulf Countries and Far East.

Al-Shamlan, K. (1993). Diving Industry (2nd ed.). Bahrain.

Al-Shamlan, M. (1975). History of Pearl Diving in Kuwait and Persian Gulf. Kuwait: University of Kuwait.

Ameen, A. M. (1987). Studies in the European commercial and political activity in Asia, 1600-1800. Amman.

Ameen, A. M. (1987). The early stages of competition among old caravan routes and New Cape Road.

Arnold, T, W. (1982). History of the Gulf (2nd ed.). Sijil Al-Arab Press.

Duran, E. (1996). Bahrain Monetary Agency. History of money in Bahrain, Bahrain Monetary Agency.

Great Britain. (1792). India Office, Marine Records (Vol. 891).

Great Britain. (1790). India Office, Marine Records (Vol. 891).

Great Britain. (1764). Letters from Bussara, Cambroon, Bushier, Letters from Bussara (Vol. 21).

Lewis, B. (1978 ). Report, British Political Resident in the Persian Gulf, 1863 (1st ed.). London, Macmillan Press Ltd., Published.

Lorimer. (1967). Guide to the Gulf, historical and geographic section (Vol. 14). Doha, Diwan Office.

Olivier's, O. (1967). Journey to Iraq 1794-1796. Iraqi Scientific Complex Press, Baghdad.

Othman, A. (1991). Pacific Ocean Trade in the Islamic Supremacy Era (41-904 A.H, 661-1498 A.D). Kuwait: Knowledge World.

Rahma, A. (1990). Emirates in the memory of its sons, Reading for all publishing and distribution (1st ed.).

Remarks of the Tribes. (n. d.) Trade and Resources around the share line of the Persian Gulf (Vol. 3). Records of the Emirates.

Saldanha, J. A. (1986). Selections from State Papers. Bombay, Regarding. The East India Company's Connections with the Persian Gulf, With Summary of Events, 1600-1800.

Share, E. (1908). Arabicized Persian words, Arab Book House, (Beirut).

Sherif, I. (1965). The Middle East, Public House Company. Baghdad. 
Sultanate of Oman. (1979). Oman and Its Maritime History. Ministry of Information.

Zahlan, R. S. (2001). The Origins of the United Arab Emirates.

\section{Copyrights}

Copyright for this article is retained by the author(s), with first publication rights granted to the journal.

This is an open-access article distributed under the terms and conditions of the Creative Commons Attribution license (http://creativecommons.org/licenses/by/3.0/). 